\title{
学童期におけるスポーツクラブ所属有無が \\ 体力・運動能力に及ぼす影響および特徵 \\ Character and influence of the existence of sports club affiliation on physical fitness and motor ability in a school period
}

\author{
古後 晴基 ${ }^{122}$, 満丸 望 ${ }^{1)}$, 久保 温子 ${ }^{1)}$, 田中 真一 ${ }^{1)}$ \\ Haruki KogO $^{12)}$, Nozomi Mitsumard1) \\ Atsuko KUbO'1), Shinichi Tanaka ${ }^{1)}$
}

\begin{abstract}
要旨：学童期のスポーツクラブ所属の有無が体力・運動能力に及ぼす影響, および体力・ 運動能力の項目間の関連を検討した。児童33名を対象として，スポーツクラブに関して質 問紙で調査し, 体力・運動能力は 9 項目測定した。体力・運動能力をスポーツクラブ所属 有無の 2 群間で比較し, 体力・運動能力 9 項目間の相関を検証した。その結果，スポーツ クラブ所属有無の 2 群間に有意差は認められなかった。握力・上体起こし・反復横跳び . $50 \mathrm{~m}$ 走・立ち幅跳びとソフトボール投げ間，反復横跳び・立ち幅跳びと上体起こし間， 50 $\mathrm{m}$ 走・立ち幅跳びと反復横跳び間，立ち幅跳びと $50 \mathrm{~m}$ 走間に，相関が認められた。これ らのことから, 学童期のスポーツクラブ所属の有無で, 体力・運動能力に差が生じないこ とが示された。ソフトボール投げは総合的な運動能力であり，敏捷性と跳躍力を発揮する には腹筋が重要な役割を担っていることが示された。また，敏捷性のある児童はスピード や跳躍力においても高い能力を有していることが示された。
\end{abstract}

キーワード：児童, スポーツクラブ, 体力・運動能力

\begin{abstract}
This study evaluated the influence of the existence of sports club affiliation on physical fitness and motor ability in a school period and the relationship between the items of physical fitness and motor ability. The participants were 33 schoolchildren. We investigated the sports club and measured nine items of physical fitness and motor ability. Two groups were compared for physical fitness and motor ability given the existence of sports club affiliation. We investigated the relationship for nine items of physical fitness and motor ability. As a result, none of the measurement items exhibited a significant difference between the two groups given the existence of sports club affiliation. There was a significant correlation between softball throw and grip strength, sit-ups, lateral-repetitive vault,50 $\mathrm{m}$ run, and stand-width jump and between sit-ups and lateral-repetitive vault and stand-width jump. There was also a significant correlation between the lateral-repetitive vault and the $50 \mathrm{~m}$ run and stand-width jump and between the $50 \mathrm{~m}$ run and stand-width jump. It was suggested that a difference does not arise in the physical fitness and motor ability given the existence of affiliation of the sports club, softball throw was an indicator of synthetic motor ability, and the rectus abdominis bore an important role in demonstrating agility and saltation. The schoolchildren with high agility also had high ability in speed and saltation.
\end{abstract}

Key words: schoolchildren, sports club, physical fitness and motor ability

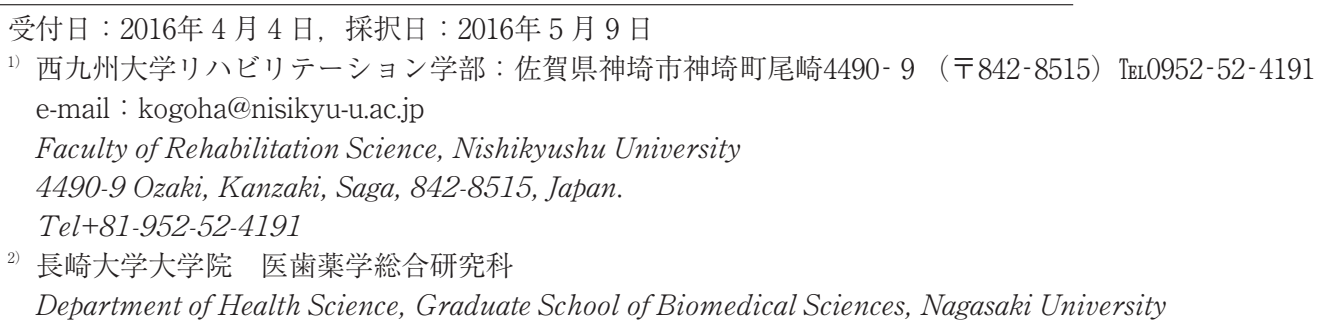




\section{I 。緒 言}

近年, 我が国における青少年の体力 ·運動能力は低 下の一途をたどっている1)と，言われてきた。このこ とは, 朝食の欠食やバランスの取れていない栄養状態 ${ }^{2}$, 塾・習い事に伴う遊び時間の減少 ${ }^{3)}$, 就寝時間の遅れ や睡眠不足 ${ }^{2)}$, 遊び場の減少やゲームの普及など2,3), 青少年を取り巻く社会環境や生活習慣の様々な要因が 絡み合って生じていると考えられている。

文部科学省によって, 新体力テスト ${ }^{4}$ に基づく体力 運動能力調査 ${ }^{5)}$ が, 平成10年度から全国的に実施され ている。そのため，青少年においても新体力テストに 基づた体力 · 運動能力の長期的な年次比較が可能と なった。旧体力テストに基づく体力・運動能力調査を 昭和60年度から眺めてみると, 巟童の握力（11歳児の みの調査 $) \cdot 50 \mathrm{~m}$ 走・立ち幅とび・ソフトボール投げ (ハンドボール投げ：女子）・反復横とび（11歳児の みの調査）のすべて調査項目が，平成 9 年度までの 14 年間年々下降している。

しかし, 平成10年の新体力テスト施行後の年次変化 を平成26年度の体力・運動能力調査における年次推移 の結果 ${ }^{6}$ からみると, 握力・立ち幅とび・ソフトボー ル投げは下降傾向であるが，長座体前屈は横ばいで, 上体起こし・反復横跳びは向上傾向であり，合計点で は緩やかに向上傾向が示されている。このことは，小 学校の体育主任研修会の開催や体力向上に向けた活動 や施策による一定の成果と言われている3 がら, スポーツクラブ所属の有無によって, 体力・運 動能力に差がある傾向が一部報告されており ${ }^{7)}$, この ことが児童の体力・運動能力向上傾向の要因であるこ とを否定できないが証明されていない。

そこで本研究は，学童期におけるスポーツクラブ所 属の有無が，体力・運動能力に及ぼす影響を明らかに することを目的とした。また, 児童を対象として体力・ 運動能力の特徵を検証した先行研究は少なく知見にそ しい。そのため, 本研究は，学童期における筋厚や筋 硬度を含めた体力・運動能力の項目間の関連を明らか にすることも合わせて検討した。

\section{II. 方 法}

\section{1. 対 象}

対象は, A小学校に通う学童保育児童の39名の内, 中学年の $3 \cdot 4$ 年生児童33名（男子 20 名, 女子 13 名） とした（表 1 ）。除外基準は，サンプル数が集まらな かった低・高学年の児童, 測定データに欠損值がある 者, および研究協力が途中で得られなくなった者とし た。

倫理的配慮として，ヘルシンキ宣言に基づき，対象 者の保護者および本人に研究の趣旨と内容を十分説明 し，得られたデー夕は研究以外には使用しないこと， 個人情報の取り扱いには十分配慮すること，および研 究の途中で拒否することが可能であることに加えて, 研究への参加は自由意志であり，参加しなくても不利 益にならないことを書面にて説明し，同意書に署名を 得て研究を開始した。

\section{2. 方 法}

\section{1 ）スポーツクラブ調査}

質問紙にて，スポーツを体育以外に実施しているか 調査した。質問項目は,「スポーツクラブや運動部に 入っていますか？」，「そのスポーツは何をしています か？」，「そのスポーツを初めて何年になりますか？」， 「スポーツをする頻度は週にどのくらいですか？」,

$「 1$ 日に何時間くらいしますか？」の 5 項目とした。 2 ）体力・運動能力の測定

測定項目は，文部科学省の示した新体力テスト実施 要項（ 6 ～11歳対象 $)^{4)}$ を参考にした握力, 上体起こ し，長座体前屈，反復横とび， $50 \mathrm{~m}$ 走，立ち幅跳び, およびソフトボール投げの 7 項目に, ハムストリング スの筋厚と筋硬度を加えた合計 9 項目とした。

\section{(1) 握力}

被験者の姿勢を自然に開いた足幅の立位とし，上肢 を体に付けない下垂位で，前腕回内外中間位とした。 測定機器はデジタル握力計（T.K.K. 5401, 竹井機器 工業）を使用し，左右交互に 2 回ずつ測定を行った。

表 1 対象者の属性 $(\mathrm{n}=33)$

\begin{tabular}{lrcrr}
\hline & $\begin{array}{c}\text { 中学年男子 } \\
(\mathrm{n}=20)\end{array}$ & $\begin{array}{c}\text { 中学年女子 } \\
(\mathrm{n}=13)\end{array}$ & $\begin{array}{r}9 \text { 歳男子 } \\
\text { 全国平均 }\end{array}$ & $\begin{array}{r}9 \text { 歳女子 } \\
\text { 全国平均 }\end{array}$ \\
\hline 年齢 $(\mathrm{year})$ & $9.1 \pm 0.6$ & $8.8 \pm 0.7$ & & \\
身長 $(\mathrm{cm})$ & $135.7 \pm 6.1$ & $136.2 \pm 8.1$ & $133.6 \pm 5.5$ & $133.2 \pm 6.0$ \\
体重 $(\mathrm{kg})$ & $30.8 \pm 4.4$ & $31.2 \pm 4.9$ & $30.0 \pm 5.0$ & $29.1 \pm 4.8$ \\
\hline
\end{tabular}

Mean \pm SD 
左右それぞれの最大值を握力とし, 左右の平均值を統 計解析の代表值とした。

(2) 上体起こし

被験者の姿勢は，背臥位にて両手を軽く握り，両上 肢を胸部の前で組ませ, 両膝関節 $90^{\circ}$ 屈曲位とし, 検 者が被験者の両膝を押さえ固定した。検者の合図で被 験者は背臥位姿勢から両肘が両大腿部に付くまででき る限り上体を起こし，30秒間で何回できるかをカウン トした。ただし, 背臥位姿勢に戻したとき, 背中がマッ トに付かない場合はカウントしないことにした。測定 回数は 1 回とし，その数を統計解析の代表值とした。

\section{(3) 長座体前屈}

被験者の姿勢は，壁に背中と臂部を付け，両足を揃 えた膝関節伸展位の長座位とし, 足関節は中間位とし た。測定には，デジタル長座体前屈計（T.K.K. 5412, 竹井機器工業）を使用した。被験者に両上肢を伸ばし， 機器の台の淵に第 $2 \sim 5$ 指を載せて拇指を下に掛けた 姿勢をとらせ，その姿勢からゆっくり体幹を前屈させ て，できるだけ遠くまで機器を滑らせた移動距離を測 定した。測定回数は 2 回とし, その最長距離を統計解 析の代表值とした。

(4) 反復横とび

屋内にて床の上に中央のラインを引き, その両側100 $\mathrm{cm}$ のところに 2 本の平行ラインを引いた。被験者は, 中央ラインを跨いで立ち，「始め」の合図で左右どち らかのラインを越すか踏むまでサイドステップし，次 に中央ラインに戻らせ，さらに反対側ラインを越すか 踏むまでサイドステップした。この動作を20秒間繰り 返し，それぞれのラインを通過するごとに 1 点カウン トした。測定回数は 2 回とし，その最高点を統計解析 の代表值とした。

(5) $50 \mathrm{~m}$ 走

屋外にて $50 \mathrm{~m}$ の直走路を作成し実施した。被験者 のシューズは日常履いている運動靴とし，スタートの 合図で被験者を走らせた。計測は 1 回とし、ゴールラ インに胴が到達するまでに要した時間をデジタルス トップウォッチにて計測した。

\section{(6) 立ち幅跳び}

屋内にて，被験者は両足を軽く開き，つま先が踏み 切り線の前端に揃えるように立たせ，両足で同時に踏 み切り跳ばせた。計測は足部が床に着いた部位で最も 踏み切り線に近い位置と, 踏み切り前の両足の中央の 位置とを結ぶ直線距離を測定した。測定回数は 2 回と し，最長距離を統計解析の代表値とした。
(7) ソフトボール投げ

屋外にて地面上に直径 $2 \mathrm{~m}$ の円を描き，円の中心

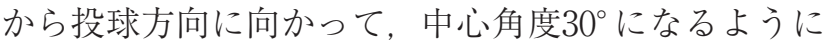
直線を 2 本引き，その間に同心円弧を $1 \mathrm{~m}$ 間隔に描 いた。被験者は，投球中および投球後に円を踏んだり 越したりすることを注意して，円内からソフトボール 1 号を自由なフォームにて投げた。記録はメートル単 位とし,メートル未満は切り捨てた。測定回数は 2 回 とし，最長距離を統計解析の代表值とした。

(8) 筋厚

筋厚を計測する筋は，柔軟性と関連があると推測さ れるハムストリングスとした。計測部位は, 先行研究8) を参考に，大転子から大腿骨外側上顆を結ぶ中点とし た。被験者の姿勢は腹臥位とし，筋収縮を起こさない ようリラックスさせた状態にて行った。計測機器は超 音波画像測定装置（HS-2200, 本多電子株式会社), リニア型プローブ（HLS-575M，本多電子株式会社）

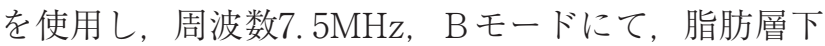
から大腿骨までの距離を左右計測した。超音波画像法 を用いた評価は，他の筋量計測法と異なり検者の技術 に左右されるため，全ての計測を同一検者にて行った。 左右の平均值を統計解析の代表值とした。

\section{(9) 筋硬度}

筋硬度を計測する筋は，筋厚の対象筋と統一したハ ムストリングスとした。計測部位は，筋厚の計測部位 に統一し，大転子から大腿骨外側上顆を結ぶ中点とし た。被験者の姿勢は腹臥位とし，筋収縮を起こさない ようリラックスさせた状態にて行った。計測機器は筋 硬度計（NEUTONE TDM-Z1，TRY-ALL 社）を使用 し，目的筋に対して筋硬度計を垂直にブザーが鳴るま でゆっくり押しあて左右計測した。本研究で用いた筋 硬度計は検者内の再現性および検者間の信頼性が認め られているが9，検者は全て同一検者とし，計測值が 安定するまで事前に練習を重ねて計測に臨んだ。計測 は左右 3 回ずつ行い，3 回の計測值の平均をそれぞれ の計測值とした。計測值を $\mathrm{N}=0.0258 \times$ 計測值 +0.4 の式 ${ }^{10)}$ に投入して，単位をニュートン $[\mathrm{N}]$ に換算し た。左右計測值の平均值を統計解析の代表値とした。

\section{3 ) 統計解析}

統計解析は, 男女別にスポーツクラブ所属有無の 2 群に分けて，二元配置分散分析を用いて体力・運動能 力の測定項目を比較した。また，男女すべてを対象と し，体力・運動能力の測定項目間をPearson の相関 係数にて関連を分析した。統計処理には，統計解析ソ 
フトウェアStat View Ver5.0を用いて分析し，有意 水準は全て 5 \%とした。

\section{III. 結 果}

質問紙によるスポーツクラブ調査結果を表 2 に，体 力・運動能力の測定結果を表 3 に示す。男女それぞれ
において, スポーツクラブ所属有無の 2 群間に, すべ ての測定項目で有意差は認められなかった。

体力・運動能力の関連に関して, 有意な相関関倸が 認められたのは，握力とソフトボール投げ（相関係数 $0.56)$ ，上体起こしと反復横跳び（相関係数 $0.53 ）$, 上 体起こしと $50 \mathrm{~m}$ 走 (相関係数 -0.42$)$, 上体起こしと

表 2 スポーツクラブ調査の結果 $(\mathrm{n}=33)$

\begin{tabular}{|c|c|c|}
\hline & 男子（n=20） & 女子 $(n=13)$ \\
\hline スポーツクラブ所属の有／無（名） & $12 / 8$ & $7 / 6$ \\
\hline スポーツの種類：サッカー（名） & 5 & 0 \\
\hline : スイミング (名) & 5 & 1 \\
\hline ：野球（名） & 3 & 1 \\
\hline : バスケットボール（名） & 1 & 0 \\
\hline : バレーボール（名） & 0 & 4 \\
\hline : 合気道（名） & 0 & 1 \\
\hline :ダンス (名) & 0 & 1 \\
\hline スポーツ歴（年） & $2.1 \pm 1.1$ & $0.8 \pm 1.1$ \\
\hline スポーツの頻度（日／週） & $2.2 \pm 1.6$ & $2.3 \pm 1.5$ \\
\hline スポーツ1日あたり実施時間（時間／日） & $2.3 \pm 1.1$ & $2.9 \pm 1.2$ \\
\hline
\end{tabular}

Mean \pm SD

表 3 スポーツクラブ所属有無別の測定值 $(n=33)$

\begin{tabular}{lcccc}
\hline & $\begin{array}{c}\text { 所属有 } \\
\text { 男子 }(\mathrm{n}=12)\end{array}$ & $\begin{array}{c}\text { 所属無 } \\
\text { 男子 }(\mathrm{n}=8)\end{array}$ & $\begin{array}{c}\text { 所属有 } \\
\text { 女子 }(\mathrm{n}=7)\end{array}$ & $\begin{array}{c}\text { 所属無 } \\
\text { 女子 }(\mathrm{n}=6)\end{array}$ \\
\hline 握力 $(\mathrm{kg})$ & $13.6 \pm 2.2$ & $14.6 \pm 3.2$ & $14.6 \pm 3.4$ & $12.2 \pm 1.0$ \\
上体起こし $($ 回 $)$ & $17.2 \pm 5.0$ & $16.1 \pm 3.5$ & $17.1 \pm 4.1$ & $12.0 \pm 6.6$ \\
長座体前屈 $(\mathrm{cm})$ & $29.8 \pm 4.3$ & $29.7 \pm 6.3$ & $31.3 \pm 3.5$ & $31.3 \pm 5.6$ \\
反復横跳び $($ 点 $)$ & $36.9 \pm 5.7$ & $38.6 \pm 3.7$ & $38.9 \pm 6.0$ & $35.5 \pm 2.6$ \\
$50 \mathrm{~m}$ 走 $($ 秒 $)$ & $9.3 \pm 0.5$ & $9.2 \pm 0.5$ & $9.8 \pm 0.6$ & $10.2 \pm 0.5$ \\
立ち幅跳び $(\mathrm{cm})$ & $148.0 \pm 14.8$ & $153.4 \pm 23.1$ & $141.9 \pm 23.9$ & $122.5 \pm 10.5$ \\
ソフトボール投げ $(\mathrm{m})$ & $18.8 \pm 8.7$ & $15.9 \pm 6.8$ & $15.2 \pm 8.5$ & $9.6 \pm 1.7$ \\
笳厚 $(\mathrm{mm})$ & $29.1 \pm 3.6$ & $29.4 \pm 2.8$ & $30.0 \pm 3.8$ & $28.1 \pm 6.4$ \\
筋硬度 $(\mathrm{N})$ & $0.98 \pm 0.51$ & $0.98 \pm 0.46$ & $0.93 \pm 0.45$ & $0.97 \pm 0.48$ \\
\hline
\end{tabular}

Mean \pm SD

表 4 体力 $\cdot$ 運動能力の相関係数

\begin{tabular}{|c|c|c|c|c|c|c|c|c|c|}
\hline & 握力 & $\begin{array}{c}\text { 上体 } \\
\text { 起こし }\end{array}$ & $\begin{array}{c}\text { 長座体 } \\
\text { 前屈 }\end{array}$ & $\begin{array}{c}\text { 反復 } \\
\text { 横跳び }\end{array}$ & $50 \mathrm{~m}$ 走 & $\begin{array}{l}\text { 立ち幅 } \\
\text { 跳び }\end{array}$ & $\begin{array}{c}\text { ボール } \\
\text { 投げ }\end{array}$ & 筋厚 & 筋硬度 \\
\hline \multicolumn{10}{|l|}{ 握力 } \\
\hline 上体起こし & 0.29 & & & & & & & & \\
\hline 長座体前屈 & 0.11 & -0.04 & & & & & & & \\
\hline 反復横跳び & $0.38^{*}$ & $0.53^{* *}$ & 0.09 & & & & & & \\
\hline $50 \mathrm{~m}$ 走 & $-0.39^{*}$ & $-0.42^{*}$ & 0.02 & $-0.51^{* *}$ & & & & & \\
\hline 立ち幅跳び & $0.39^{*}$ & $0.55^{* *}$ & 0.18 & $0.55^{* *}$ & $-0.64^{* *}$ & & & & \\
\hline ボール投げ & $0.56^{* *}$ & $0.53^{* *}$ & -0.05 & $0.65^{* *}$ & $-0.57^{* *}$ & $0.63^{* *}$ & & & \\
\hline 筋厚 & 0.10 & 0.30 & 0.26 & 0.24 & -0.29 & 0.11 & 0.24 & & \\
\hline 筋硬度 & $0.36^{*}$ & 0.03 & 0.17 & 0.13 & -0.10 & 0.11 & 0.05 & 0.11 & \\
\hline
\end{tabular}


立ち幅跳び (相関係数0.55), 上体起こしとソフトボー ル投げ（相関係数 0.53 ), 反復横跳びと $50 \mathrm{~m}$ 走（相関 係数 -0.51$)$, 反復横跳びと立ち幅跳び(相関係数 0.55$)$, 反復横跳びとソフトボール投げ（相関係数 $0.65 ）, 50$ $\mathrm{m}$ 走と立ち幅跳び（相関係数-0.64）, $50 \mathrm{~m}$ 走とソフ トボール投げ（相関係数 - 0.57）, 立ち幅跳びとソフ トボール投げ（相関係数0.63）であった（表 4 ）。

弱い相関関係が認められたのは，握力と反復横跳び (相関係数 0.38 ), 握力と $50 \mathrm{~m}$ 走（相関係数 $-0.39 ）$, 握力と立ち幅跳び（相関係数0.39）, 握力と八ムス卜 リングス筋硬度（相関係数0.36）であり，その他の項 目間は相関関係が認められなかった（表 4$)$ 。

\section{IV. 考 察}

本研究は，学童期におけるスポーツクラブの所属が, 体力・運動能力に及ぼす影響を検証する目的で行い, 男女それぞれにおいて，スポーツクラブ所属有無の 2 群間にすべての測定項目で有意差は認められなかった。

平成26年度体力 ・運動能力調査結果における「運

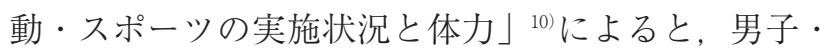
女子ともに, 運動部やスポーツクラブや運動部へ所属 している群の方が, 所属していない群よりも合計点が 高い傾向にあった。さらに 6,7 歳では, 運動実施頻 度による合計点の差は小さいが，8歳ごろからは加齢 に伴って合計点が増加し，ほとんどの年代において運 動やスポーツを実施する頻度が高いほど，合計点が高 い傾向にあった ${ }^{11}$ 。また，高学年児童を対象とし，新 体力テスト合計点と身体活動との関連を検証した先行 研究3)では, 男子は運動量・総消費量との間に, 女子 は運動量・総消費量・歩行距離との間に有意な相関が 認められている。また, 児童を対象として生活習慣の アンケート結果を得点化して, 体力・運動能力との相 関を検証した先行研究 ${ }^{22}$ によると, 女子では新体力テ ストの合計点と運動・スポーツクラブの所属との間に, 有意な弱い正の相関が認められている。本研究におい て, 体力・運動能力調査のように合計点で検討しな かった理由は, 調查結果が傾向しか示されていないこ とや測定項目ごとに検討したかったためである。その 結果，女子はスポーツクラブ所属群が対照群と比べて， いくつかの測定項目において高い傾向が観られる。し かし, 男女ともに有意差が認められなかったため, 久 ポーツクラブ所属による影響はあまりないと考えられ る。

また，本研究は学童期における体格・運動能力の測
定項目間の関連を検証した結果，握力・上体起こし・ 反復横跳び・ $50 \mathrm{~m}$ 走・立ち幅跳びとソフトボール投 げの間, 反復横跳び・立ち幅跳びと上体起こしの間, $50 \mathrm{~m}$ 走・立ち幅跳びと反復横跳びの間，立ち幅跳び と $50 \mathrm{~m}$ 走の間に相関関係が認められた。また，長座 体前屈, 筋厚および筋硬度と相関関係が認められる項 目はなかった。

ヒトの体格が思春期に急増する Adolescent growth spurt（AGS） ${ }^{13)}$ という時期があるが，本研究の対象 は中学年児童であるため, AGS の発現時期の相違か ら生じる身体特性（体格）の影響によって，体力・運 動能力結果に体格差が生じている可能性は少ないと思 われる。足立ら ${ }^{14}$ は，小学 5 年時から中学 2 年時にか けて縦断的に体力・運動能力を調査し, 小学 5 年時と 中学 2 年時の体格・運動能力の関連を検証した。その 結果，相関係数が 0.5 以上の比較的強い相関を示した ものは，男子では握力， $50 \mathrm{~m}$ 走とボール投げであり， 女子では握力, 上体起こし, $50 \mathrm{~m}$ 走, 立ち幅跳びと ボール投げであったと報告している。男女ともに中学 2 年時のボール投げは, 小学 5 年時の体力・運動能力 と関連があることが認められている。本研究において, 児童期におけるソフトボール投げが，他の体力・運動 能力と相関関係を示したことは，巧較性 ${ }^{1)}$ の指標であ るボール投げは，総合的な運動能力の指標であると考 えられる。また，主に腹筋を使用する上体起こしが反 復横跳び，立ち幅跳びと関連が認められたことは，敏 捷性（反復横跳び）と跳躍能力 ${ }^{15)}$ (立ち幅跳び）を発 揮するには，腹筋が重要な役割を担っていることが示 されたと考えられる。さらに，反復横跳びは，50m 走や立ち幅跳びと関連が認められ，敏捷性（反復横跳 び）のある児童はスピード (50m 走) や跳躍能力（立 ち幅跳び）においても高い能力を有していることが示 された。

本研究の筋厚と筋硬度の計測筋は, 柔軟性に関連が 推測されるハムストリングスとした。19歳から69歳ま

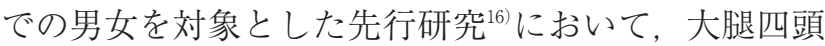
筋の筋厚は大腿周径，体重，およびBMI と強い相関 関係が示されている。また, Scholten ら ${ }^{17}$ は，超音波 画像法を用いて生後11週から16歳までの青少年の筋厚 を計測し，筋厚を従属変数に，年齢，身長，体重，お よび性別のパラメーターを独立変数として，重回帰分 析を行った。その結果, 独立して関与するパラメーター は体重のみであったと報告している。以前，著者らは， 幼児の筋厚は運動習慣などで増減するより，体格の影 
響が大きいことを明らかにした ${ }^{18)}$ 。これらの知見から， 幼児や児童は筋の発達が未熟なため, 筋厚は体格の中 でも体重に大きく依存おり, 本研究において, 筋厚と 関連が認められる測定項目がなかったと考えられる。 筋硬度は筋萎縮などの質的変化を評価することが可能 であり，筋収縮強度により変化するものである ${ }^{199}$ 。本 研究の被験者にスポーツクラブ（運動部含む）に所属 する览童が含まれているが，スポーツ頻度は平均週に 約 2 日で 1 日約 2.5 時間であり, 筋の質的変化が起こ る程度のスポーツ強度でないかもしれない。長座体前 屈は柔軟性の指標である測定項目である。長座体前屈 に関与している筋はハムストリングスや脊柱起立筋な どである。しかし，八ムストリングスの筋厚や筋硬度 と関連が認められなかったことは，览童期は成長過程 であり，柔軟性に個人差があまり生じていないと考え た。

本研究結果から, 中学年の坚童において, スポーツ クラブ所属の有無で体力・運動能力に差が生じないこ とが示唆された。また, 巧嘾性のソフトボール投げは 総合的な運動能力の指標であり, 敏捷性と跳躍能力を 発揮するには腹筋が重要な役割を担っている可能性が 示唆された。さらに, 敏捷性のある児童はスピードや 跳躍能力においても高い能力を有していることが示さ れた。

しかし, 本研究は児童の体力・運動能力の代表值と して取り扱うにはサンプルサイズが小さいことが本研 究の限界である。しかしながら, 児童の生活習慣が体 力・運動能力に及ぼす影響を検証していくことは, 生 涯にわたって健康を維持増進させていくための重要な 要素であり, 理学療法の臨床扮よび研究の分野に扒い て有用な知見が得られると考える。そのため, 幅広い 年齢の青少年を対象として, データの蓄積を行ってい くことが今後の課題である。

\section{引用文献}

1) 有川秀之, 太田涼, 駒崎弘匡 - 他 : 小学生の投能力向上の 一考察. 埼玉大学教育学部附属教育実践総合センタ一紀要, 2005, 4, 95-105

2 ）宮下和, 本山貢, 木場田昌宣：小学生の生活習慣が体力に 及ぼす影響について。和歌山大学教育学部教育実践総合七 ンター紀要，2010，20，125-131

3 ）新本惣一郎, 山崎昌廣: 小学生の体力と身体活動量の関係. 発育発達研究，2013，61，9-18.

4) 文部科学省ホームページ：新体力テスト実施要項（6 11 歳対象).

http://www.mext.go.jp/a_menu/sports/stamina/03040901. htm（閲覽日：2016／3／8）

5 ）文部科学省ホームページ：体力・運動能力調査 http:// www. mext. go.jp / b_ menu / toukei / chousa 04 / tairyoku/1261241.htm（閲覽日：2016/3/8）

6 ）文部科学省ホームページ：平成 26 年度体力・運動能力調查 結果の概要; 体力・運動能力の年次推移の傾向（青少年） http://www.mext.go.jp/component/b_menu/other/__icsFiles/afieldfile/2015/10/13/1362687_02.pdf（閲 覧 日： $2016 / 3 / 8)$

7 ) 文部科学省ホームページ：平成 26 年度体力・運動能力調查 http://www.e-stat.go.jp/SG1/estat/List.do?bid=000001054 955\&cycode $=0 （$ 閲覧日：2016 $/ 3 / 14 ）$

8 ）福元喜啓, 池添冬芽, 山田陽介-他：超音波画像診断装置 を用いた骨格筋の量的・質的評価。理学療法学，2015，42 (1) : 65-71.

9）高梨晃, 烏野大, 塩田琴美 - 他 : 2 種類の軟部組織硬度計 に扔ける再現性，信頼性の検討．理学療法科学，2008，23 (2) : 297-300.

10）古後晴基，黑沢和生，長谷部敦子・他：筋硬度の定量化な らびに筋硬結に扔ける筋疼痛と筋硬度との関連性. 理学療 法科学, 2010, 25(1)：41-44.

11）文部科学省ホームページ：平成26年度体力・運動能力調查 結果の概要; 運動・スポーツの実施状況と体力 http://www.mext.go.jp/component/b_menu/other/__icsFiles/afieldfile/2015/10/13/1362688_07.pdf

12）関耕二, 米嶋美智子, 西田彰訓・他 : 小学生の足指筋力と 体力や生活習慣の関倸について. 地域学論集，2014，10(3)， 135-144.

13) Gasser T, Muller HG, Kohler W, et al: An analysis of the mid -growth and adolescent spurts of height based on acceleration. Ann Hum Biol, 1985, 12(2): 129-148.

14）足立稔，酒向治子，笹山健作： 3 年間にわたる子どもの体 力縦断的変化が形態, 生活習慣, 心身の健康指標におよほ す影響. 岡山大学大学院教育学研究科研究集録, 2013，153, 81-87.

15）久保温子, 平尾 文, 入部健次郎 - 他：幼児期に打ける運 動能力の性差. 理学療法さが, 2015, 1 (1)：31-34.

16）宮本賢作，田中聡，田中愛・他：超音波皮脂厚計を用いた 下肢筋厚測定值の妥当性と筋力・筋量との関連について. 形態・機能, 2007, 6 (1)：27-32.

17) RR Scholten, S Pillen, A Verrips, et al:: Quantitative ultrasonography of skeletal muscles in children: Normal values. Muscle Nerve, 2003, 27(6): 693-698.

18）古後晴基，村田 伸，村田 潤・他：幼児に打ける体格と 運動機能の性差㧍よび超音波画像法を用いて計測した筋厚 との関連. ヘルスプロモーション理学療法研究, 2015, 5 (3) : 107-112.

19）古後晴基，村田 伸，甲斐義浩・他：大腿前面筋群におけ る等尺性収縮強度の違いによる筋硬度変化. 理学療法, 2012, 29(11) : 1279-1283. 